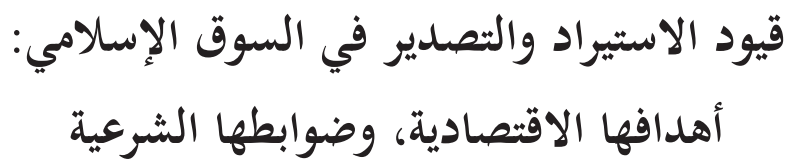

\title{
Restrictions on Importation and Exportation in Islamic Market: Economic Goals and Shariah Parameters
}

\author{
al-Meqdad Ali al-Shami*
}

\begin{abstract}
Prior to agriculture, international trade is deemed one of the oldest human activities since ages, as Allah Almighty bestowed different countries with different wealth and made them in need for each other. Import and export are the most important activities in international trade currently. In relation to this, this study aims to shed some light on sharia regulations pertaining to both activities in Islamic market; and to identify the economic goals of import and export activities as well as restrictions imposed on them. The study is based on deductive methodology by analyzing theories from general to specific. The study finds that there are two types of restriction in Shariah: first, restrictions that directly affect the control of the quantity of goods imported and exported, and the second restrictions are those that indirectly affect the
\end{abstract}

* Assistant Professor, Academic of Islamic Studies and Arabic Language (AISAL), University College of Yayasan Pahang (UCYP), Meqdadali@ucyp.edu.my 
quantity of goods imported and exported. This study suggests some Shariah parameters for each type of restrictions. Failure to comply to the parameters may lead to neglect of economic goal in Shariah as well as the interest of the public and perpetuate injustice in the community.

Keywords: importation, exportation,Islamic market, Shariah parameters

\section{تعريف المصطلحات الأساسية في البحث:}

يتضح المقصود من هذا البحث بالتطرق إلى تعريفاته، وذلك من خلال

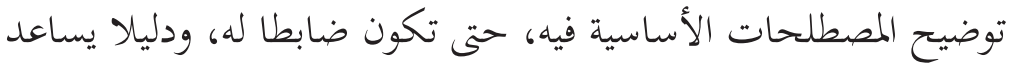

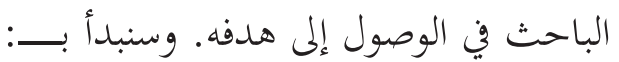

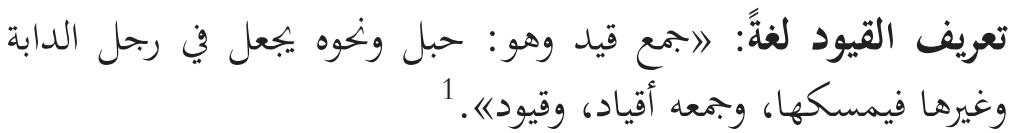
》القيد: واحد القيود. وقد قيدت الدابة. وقيدت الكتاب: شكلته《.2 القيد في الاستيراد والتصدير: يعني مصطلحاً عاماً يشمل أي قيود

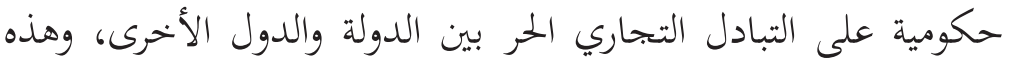

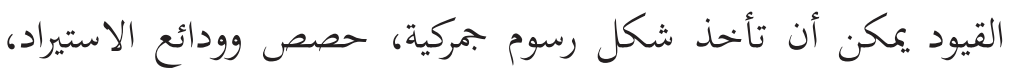

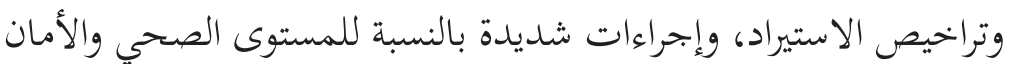

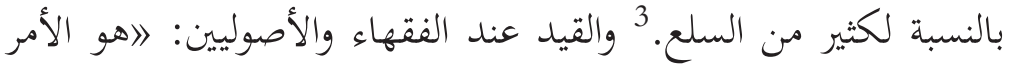

Ibrāhīm Mușțafā wa Ākharūn, al-Mu'jam al-Wasīṭ, ed. Majma’ alLughah al-'Arabiyyah (t.tp: Dār al-Da’wah, t.t), 2:769.

2 Ismā'îl bin Hammād al-Jawhurī, al-Ṣahāh Taj al-Luqhah wa Șahāh al-'Arabiyah, cet.ke-4 (Bayrūt: Dār al-'Ilm li al-Malāyīn, 1990), 3:91.

3 Husāyn 'Umar, Mawsū'ah al-Muștalahāṭ al-Iqtiṣādiyyah, cet.ke-3 (Jeddah: Dār al-Shurūq, 1399H), $\wedge 17$. 
المخصص للأمر العامهـ. وفي ضوء ذلك فإن هذا البحث تناول هذه القيود بمعناها اللغوي، وبمعناها الاصطحلاحي. لرحوي.

\section{تعريف السوق لغة: هي التي اليجلب إليها السلع للبيع والابتياع. تؤنث

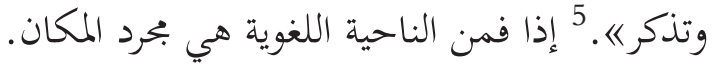

والسوق في العرف الاقتصادي: عُرّفت بالمكان الذي تتجه إليه البضائع

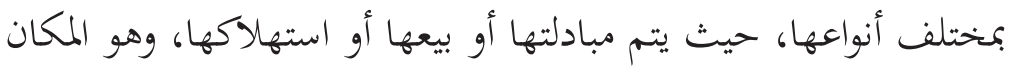

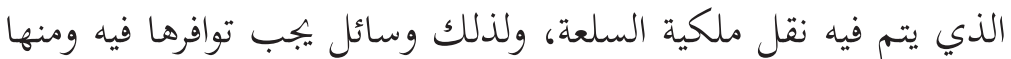
التخزين والتمويل والفرز والتوزيع.

وعلى هذا التعريف فإن السوق أوسع من بحرد المكان، فهو كل وسيلة

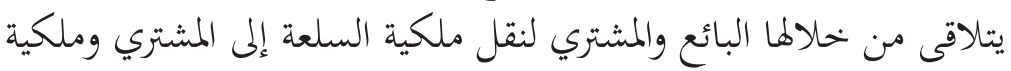

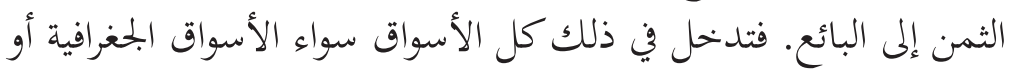
الأسواق الإلكترونية.

\section{تعريف الضوابط الشرعية:}

تعريف الضابط اصطلاحاً: عرفها الأصوليون بالأمر الكلى، الذي يطلق

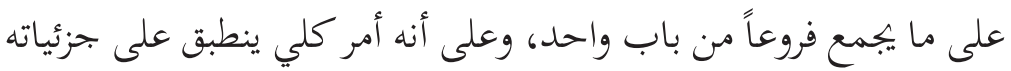

4 Muḥammad bin 'Alī Ibn al-Qāộ̄ Muḥammad Ḥamid bin Muḥammad Șābir al-Fārūqī al-Hanafì al-Ṭahānawī, Mawsū'ah Kasshāf Iștilāhāt al-Funūn wa al- 'Ulūm, ed. 'Alī Daḥrūj (Bayrūt: Maktabah Lubnān, 1996), 2:816.

5 Ibrahim Mastafiun wakharuna, al-Mu jam al-Wașit (Iskandariyyah: Dār Aldaewati, n.d.), 464-465.

6 Muḥammad Șabrī Hārūn, al-Aḥkām al-Aswāq al-Māliyyah al-Ashum wa al-Sanadāt Dawābìt al-Intifā' wa al-Tașarruf bihā fì al-Fiqh alIslāmī (al-Urdūn: Dār al-Nufāis, 1999), 15. 


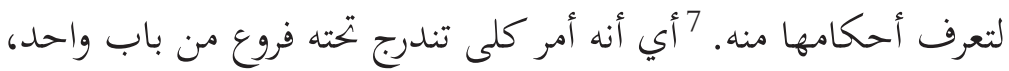

$$
\begin{aligned}
& \text { وليس من أبواب مختلفة، وقد ذكر العلماء عدة إطلاقات للضابط منها: } \\
& \text { تعريف الشيء: أي المفهوم الذي يتحدد به مسير الشيء وحركته.8 } \\
& \text { المقياس الذي يكون علامة على تحقيق معنى من المعاني. } \\
& \text { تقاسيم الشيء أو أقسامه. وكذلك أحكام فقهية عادية. } 9
\end{aligned}
$$

\section{تعريف الضوابط الشرعية للاستيراد والتصدير:}

من خلال التعريفات السابقة، وباستقراء الضوابط الشرعية له، يمكن

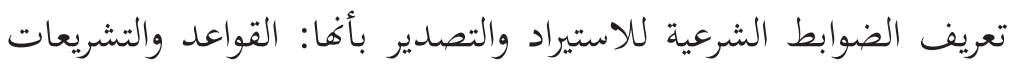

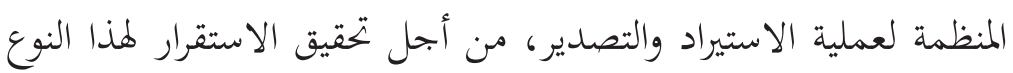
من التجارة.

\section{قيود الاستيراد والتصدير على السوق الاسلامي}

وقبل الحديث عن هذه القيود لا بد من بيان المجال الذي تطبق عليه هذه

7 Al-Ḥimwīe Aḥmad bin Muhammad Makkī al-Ḥusaynī, Ghamaz 'Uyūn al-Bașāir Sharh Kitāb al-Ashbāh wa al-Nazāir (li Zayn al'Ābidīn Ibn Nujaym al-Miṣr) (Bayrūt: Dār al-Kutub al-'Imiyyah, 1405H), 2:5.

8 Kāmil Șakr 'Azīz, "Ḍawābiṭ Istikhdām al-Mawārid al-Bashariyyah fĩ al-Iqtișād al-Islāmī wa Athāruhā fĩ al-Tanmiyah" (rișālah duktūrah, Jāmi'ah Baghdād, 1997), 8.

9 'Abd al-Majīd 'Abdullāh, al-Qawā'id wa al-Dāwābit al-Fiqhiyyah li Ahkām al-Mubì' fì al-Sharì'ah al-Islāmiyyah ('Ammān: Dār alNufāis, 2005),29 .

10 Al-Miqdād 'Alī al-Shāmī, "al-Ḍawābiṭ al-Shar'iyyah li al-Istīrād wa al-Tașdīr Dirāsah Tațbīqiyyah 'alā Qānūn al-Tijārah al-Khārijiyyah al-Yamanī li ‘Ām 2007,” (Risālah Duktūrah Jāmi’ah al-'Ulūm alIslāmiyyah, 2012), ґ^. 
القيود، والمتمثل في السوق الإسلامي، وبيان الأهداف التي يسعى إلى تمقيقها من الناحية الاقتصادية.

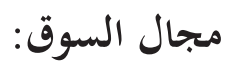

حيث يعتبر السوق ا كل بجال يكون فيه البائعون والمشترون على اتصال

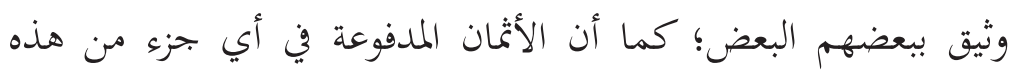

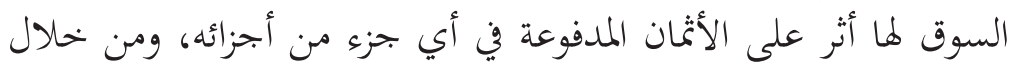

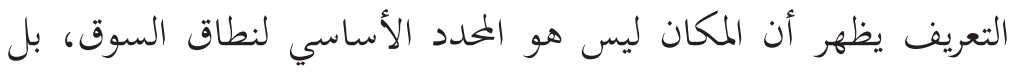

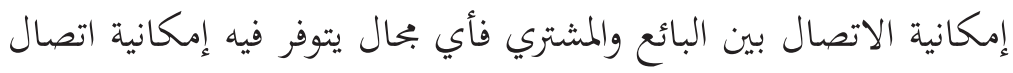

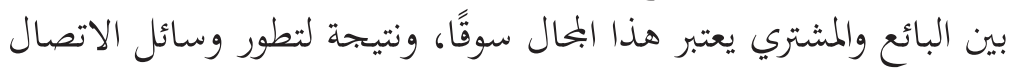

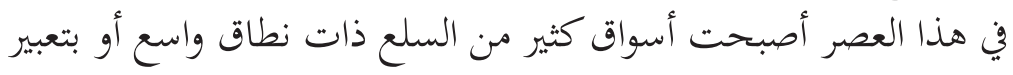

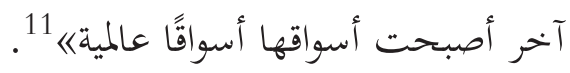

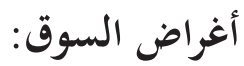

يسعى السوق من الناحية الاقتصادية لتحقيق الأهداف التالية: 1. الحصول على سعر عادل من تلاقي العرض والطلب.

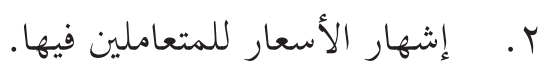
r. التعاقد على صفقات تسلم في مواعيدها. ع. تنظيم المضاربة المشروعة: أي التي تفضي إلى توازن الأسعار. ه. تنظيم تداول السلع من مصادرها إلى الصناع بواسطة التجار

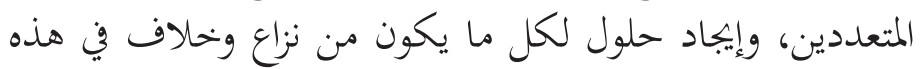

'Ilā' al-Dīn al-Rifătī, al-Sūq wa Makānatuha fì al-Islām (t.tp: tp, 2006), 2. 


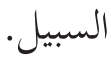

7. تحسين ظروف السلع التجارية بالعمل على النهوض بها. وغيرها التي لا يسع المحال لذكرها.

النوع الأول: القيود غير المباشرة على السوق في الاستيراد والتصدير للسوق المعاصرة قيوداً فرضتها عليها الأنظمة الاقتصادية المعاصرة؛

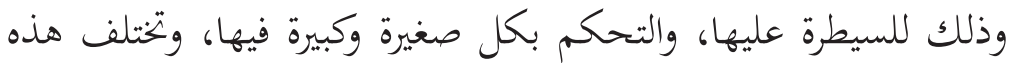

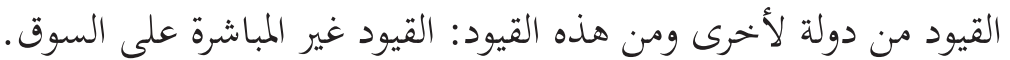

والقصد من هذه القيود هو تقييد الحرية المطلقة في التبادل التجاري، وذلك لحماية المصالح المعتبرة شرعا. 12 القيد الأول: رخصة مزاولة الاستيراد والتصدير

تعد رخصة مزاولة الاستيراد والتصدير من القيود غير المباشرة على التجارة

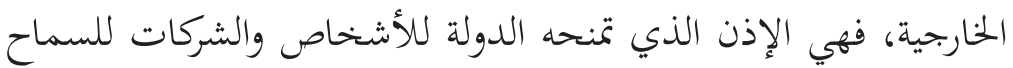

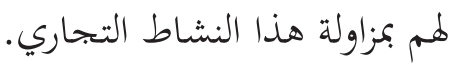

والرخصة بمعناها الخاص بالاستيراد: هي رخصة أو تصريح تصدرها إلى

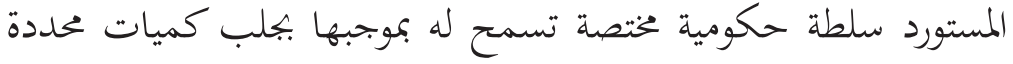

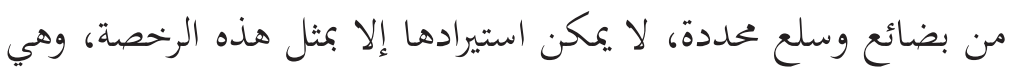

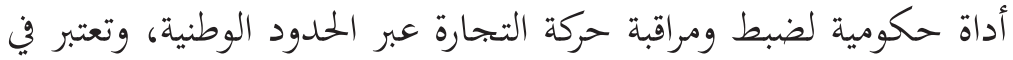
التصدير كوثيقة حكومية تسمح للمصدر بتصدير بضائع محددة إلى بلد ومدية ما 13

12 'Ikāz, Muhammad 'Alī, al-Quyūd al-Shar'iyyah al-Wāridah 'alā Huriyyah al-Tijārah wa Atharuhā fĩ al-Tanmiyah Dirāsah Fiqhiyyah Muqāranah (Miṣr: Dār al-Fikr al-Jāma'̄̄, 2008), 64.

13 Rukhsat Alaistirad, Rukhsat Altasdir. Qism Altijarat Walaistithmar," 28-05-2012, 2012, http://www.ru4arab.ru. 


\section{4: الأهداف الاقتصادية لتقييد مزاولة الاستيراد والتصدير بالرخص}

تمدف السياسات التجارية في كثير من الدول إلى تنظيم التجارة الدولية، وذلك بغرض تحقيق أغراض اقتصادية وأخرى سياسية، وأغراض أخرى لا لا

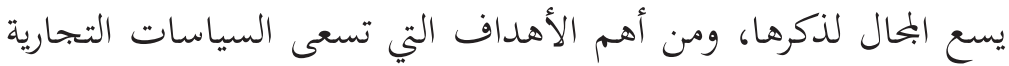
لتحقيقها هي الأهداف الاقتصادية، ويمكن تلخيصها ونا لالنقاط التالية: 1. ماية القطاعات الناشئة سواء الزراعية أم الصناعية أم غيرها من

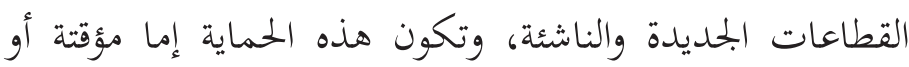
دائمة.

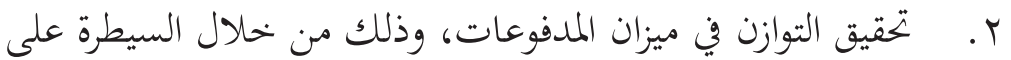

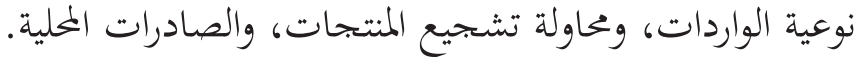

r. التحكم في الكميات المستوردة من السلع والخدمات التجارية. هذه الأهداف تتحقق من خلال ممارسة الدولة لمذا القيد ولغيره من القيود الأخرى، وذلك بسبب التشابه الكبير في نتائج تطبيق القيود المباشرة وغير المباشرة.

\section{الضوابط الشرعية لتطبيق قيد الرخص:}

بالنظر إلى حقيقة هذا الترخيص وجد الباحث أن هذا النوع من القيود يطبق على نطاق واسع حول العالم، وعليه مدار الاتفاقيات التجارية

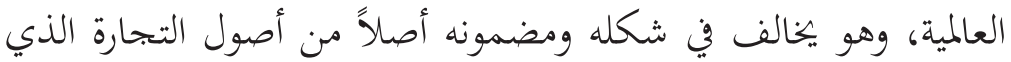
هو حرية التجارة.

فالأصل في الشريعة الإسلامية هو حرية التجارة المشروعة، وعدم تقييدها

14 Muḥammad al-Sānūsī Muḥammad Shahātah, al-Tijārah alDawliyyah fì Daw' al-Fiqh al-Islāmī wa Ittifāqiyāt al-Jād Dirāsah Muqāranah (Miṣr: Dār al-Fikr al-Jāma'ī, t.t), 209-210. 
إلا بما تقتضية الضرورة والحاجة الشرعية، وبما أن الضرورة الاقتصادية قائمة وكذلك الحاجة إليه.

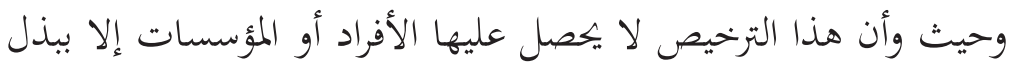

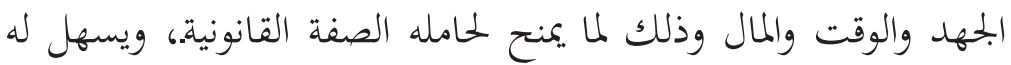
الاستفادة من التسهيلات التي توفرها الحكومات، واكتسابه لقيمة مالية. 15 والدولة تعتبر مخولة لاتخاذ الإجراءات المناسبة لحمايتها وحماية رعاياها

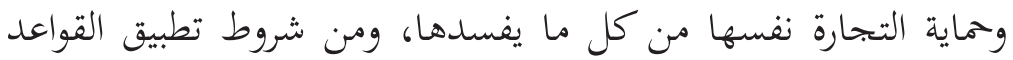

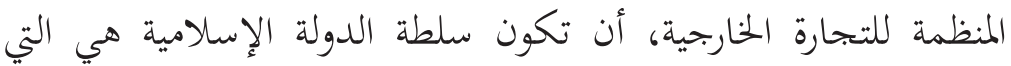

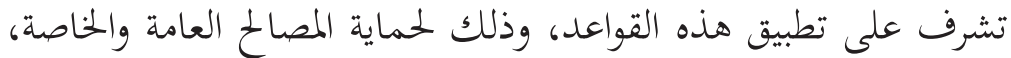

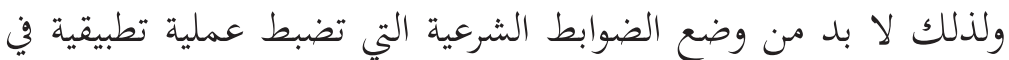

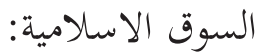

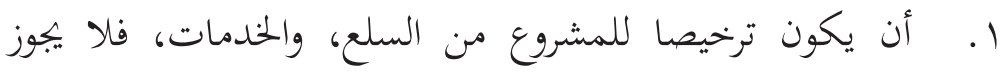
الترخيص للسلع المحرمة.

r. أن يمنح لكل من له القدرة على ذلك، وتوفرت فيه الشروط الشرعية،

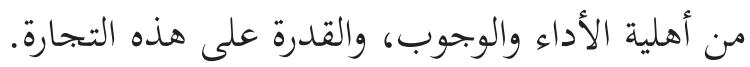

r. أن لا يتسبب هذا الترخيص بأي ضررٍ على السوق في الاستيراد

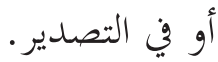
ع. ـ ألا يكون وسيلة إلى الاحتكار. ه. أن تكون معايير منحه واضحة لكل من أراد الحصول عليه. 7. أن يكون منحة مؤقتاً وليس دائماً، وذلك لمنع باب الاحتكار،

15 Muhammad Taqī al-‘Uthmān̄̄, "Bay' al-Ḥuqūq al-Mujridah,” Majallah Majma'al-Fiqh al-Islāmī vol.5, no.3 (1948), 3:1948. 


\section{وكذلك إعطاء الفرصة للآخرين.}

فبهذه الضوابط يكون الترخيص قد هُذب ليتماشى مع مقاصد الشريعة

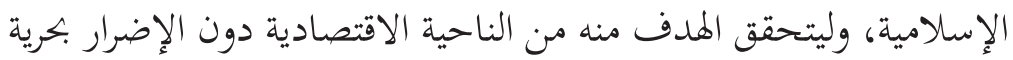

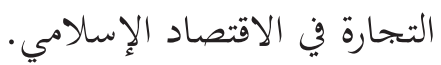

\section{القيد الثاني: حصص الاستيراد والتصدير:}

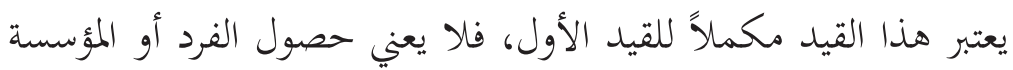

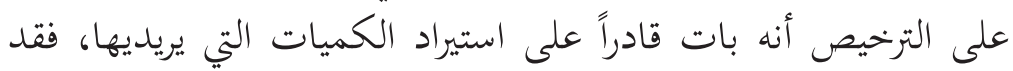

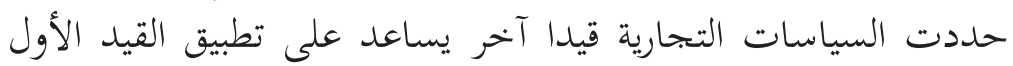
المتمثل في تراخيص الاستيراد والتصدير.

ويعتبر هذا القيد من أقدم وسائل الرقابة التجارية المباشرة على التجارة

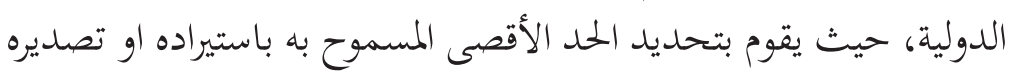
من السلع، لتحقيق بعض الأهداف الاقتصادية. 16

حيث يقوم هذا القيد بتحديد الكميات المسموح بها من الحكومة لتدخل

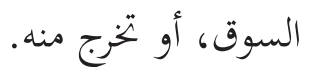

》اوقد أثنار توزيع الحصص عدة مشاكل، أهمها: كيفية توزيع هذه الحصص الحص

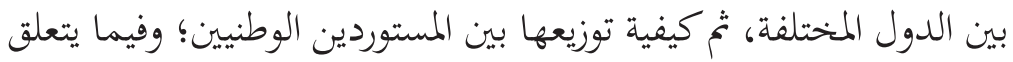
بتوزيع الحصص على المستوردين الوطنيين، فيمكن تصور طريقتين في هذا

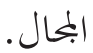

الأولى: ترك توزيع الحصص لرغبة المصدرين الأجانب حيث يقومون

$\overline{16}$ Muḥammad 'Alī Hizām al-Muqbalī, al-Ișlāhāt al-Iqtiṣādiyyāh wa In'ikāsātihā 'alā al-Tijāraj al-Khārijiyyah fì al-Jumhūriyyah al-Yamaniyyah 1990-2001 (Sana'ā: Wizārah al-Thaqāfah wa alSiyāḥah, 2001), 25. 
بتحديد المستوردين المحليين الذين يتعاملون معهم، وقد تؤدي هذه الطريقة

$$
\text { إلى كثير من المساوئ خاصة دعم الاحتكارات الأجنبية. }
$$

أما الطريقة الثانية: فتترك للدولة توزيع الحصص على المستوردين المحليين

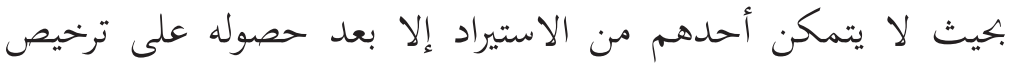

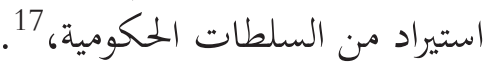

وهذه الطريقة وإن كانت تحمي استقلال الدولة وتحقق مصلحتها إلا أنه

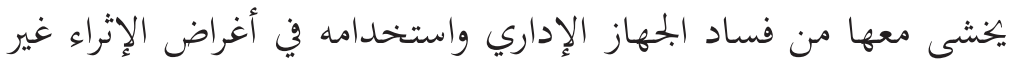

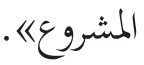

\section{أهداف هذا القيد من الناحية الاقتصادية:}

تمدف السياسات التجارية إلى تحقيق مجموعة من الأهداف الاقتصادية

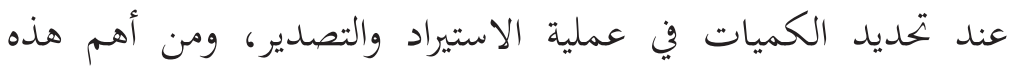

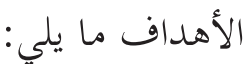
ا ـ ماية استقلال الدولة اقتصاديا. r r ماية الصناعات الناشئة.

r. السيطرة على السلع وكميات دخولها إلى الأسواق، وكذلك خروجها

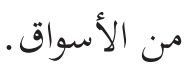

وهناك الكثير من الأهداف الاقتصادية، ولكن كما أسلفنا أنه تتداخل جميعا في تحقيق الأهداف العامة منها.

Muhammad Muḥammad al-Ghazālī, Mushkilah al-Ighrāq Dirāsah Muqāranah (Miṣr: Dār al-Jāmi’ah al-Jadīdah, 2007), 356-357. 


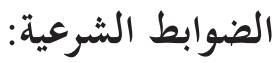

ومن الناحية الشرعية فإن هذا القيد لا يكون شرعياً إلا أن تتحقق فيه

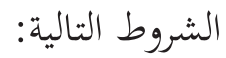

1. أن تكون هذه الحصص على سلع مباحة في الشريعة الإسلامية، فلا يجوز استيراد أو تصدير المحرمات مهما كانت كمئل ميتها.

r. أن تكون هذه الحصص لا تضر بالسوق استيراداً أو تصديراً.

r. أن تمنح هذه الحصص بحسب معايير واضحة للأفراد والشركات،

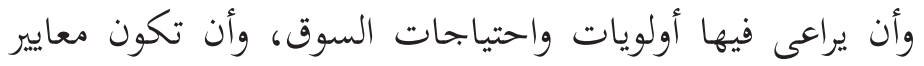

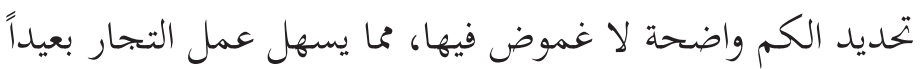
عن الواسطة والمسسوبية.

ع. أن تكون هذه الحصص لغرض مؤقت وليس لغرض دائم. ه. أن تكون هذه القيود مبنية على دراسة ومعلومات صحيحة. وعليه فمتى توفرت هذه الشروط فإن الحصص تكون مشروعة، وذلك لأن الأصل في الاستيراد والتصدير الحرية.

القيد الثالث: الرسوم أو الضريبة الجمركية على الواردات، والصادرات:

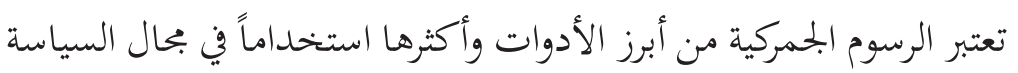

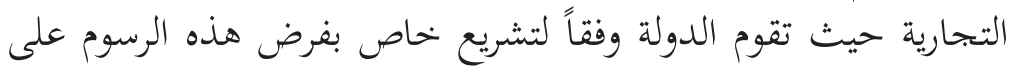

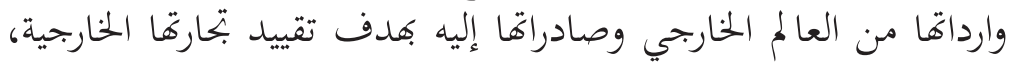


وتنظيمها. وكانت تأخذ الجمارك والعشور فقط من السلع المعدة للتجارة.18.

ويتم تحصيل هذه الرسوم الجمركية على السلع المستوردة إما على أساس

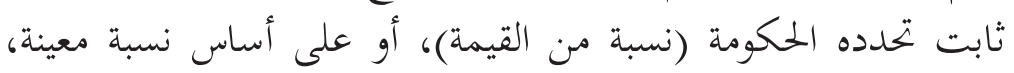

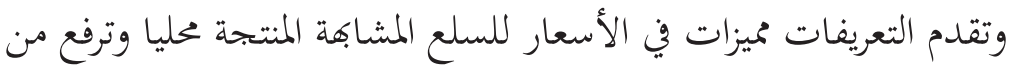
عوائد الحكومة) و 19

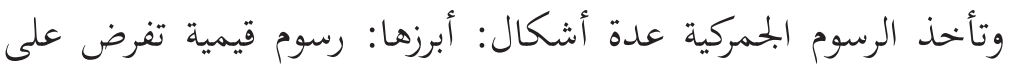

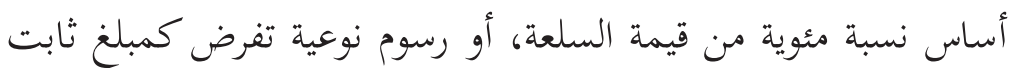
من النقود عن كل وحدة من السلعة. 20

أهداف الجمارك على الواردات والصادرات:

إن وجود هذه المصلحة الحيوية في جميع دول العالم يؤكد من أهميتها،

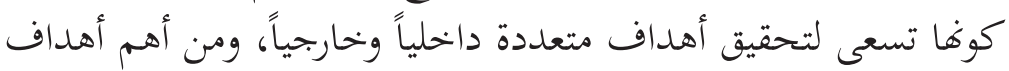
هذه المصلحة هي:

\section{أهداف دينية وسياسية:}

لفرض الضريبة الجمركية أهداف دينية وسياسية تبرر فرض هذه الضريبة

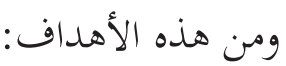

18 Aḥmad Abū al-Wafā', al- 'Ilām bi Qawā'id al-Qānūn al-Duwal̄ wa al-'Alāqāt al-Dawliyyah: F̄̄ al-Sharī'ah al-Islām, wa al-'Alāqāt al-Iqtiṣādiyyah al-Dawliyyah fì al-Sharī'ah al-Islāmiyyah, ed. ke-2 (Mișr: Dār al-Nahḍah al-'Arabiyyah, 2007), 524.

19 Munazamat al-Tijarat al-'Alamia, "al-Mustalahat al-Kamila," 2805- 2012, 2012, Ttp://Www.Wtoarab.Org/Searchword.Aspx?

20 Al-Majdhūb Asāmah, al-Jād wa Miṣr al-Buldān al- 'Arabiyyah min Hāfan ilā Marākish 1947-1994 (al-Qāhirah: al-Dār al-Miṣriyyah alLibāniyyah, 1997), 31-43. 
1. المعاملة بالمثل، وقد ظهر ذلك واضحاً في عهد أمير المؤمنين عمر

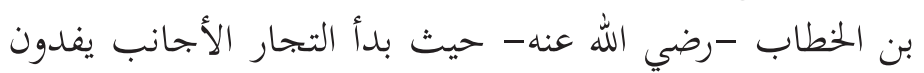
إلى الدولة الإسلامية ببضاعتهم فأمر عمر أن يعاملهم المسلمون

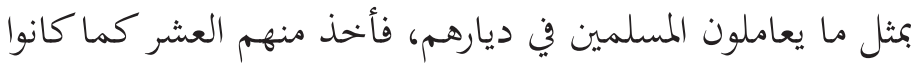

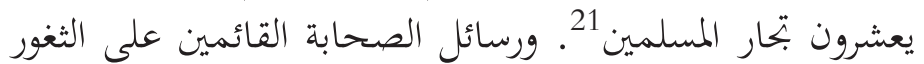
إلى الخليفة عمر بن الخطاب رضي الله عنه. 22

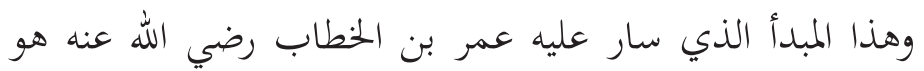

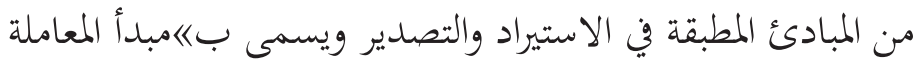

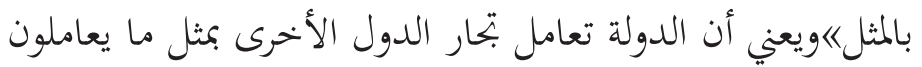
رعاياها في دفع الرسوم المفروضة عليهنم.

ץ. ماية الدولة من تصدير السلع الممنوع تصديرها للكفار. r. محاية الدولة من دخول المحرمات إليها. 23

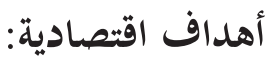

تهدف مصلحة الجمارك إلى تحقيق أهداف اقتصادية في فرضها الرسوم الجمركية على السلع المعدة للاستيراد والتصدير، ومن هذهيق إلى الأهداف: 1. تسهيل حركة التبادل التجاري بين الدول، وذلك عن طريق تنظيم

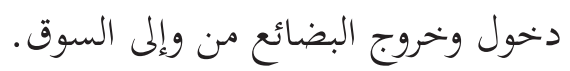

21 'Abd al-Salām Hārūn, Tahdhīb Sìrah Ibn Hisham (al-Kuwāyt: Dār al-Buhūth al-'Ilmiyyah, 1985), 60.

22 Abū Yūsuf Ya'qūb bin Ibrāhīm, al-Kharāj, ed.ke-3 (Qāhirah: alMațba'ah al-Salafiyyah, 1382H), 1:35.

23 'Ikāz, al-Quyūd al-Shar'iyyah al-Wāridah, 494. 


$$
\begin{aligned}
& \text { r . رفد خزينة الدولة بالإيرادات. } \\
& \text { r. تطبيق القيود الكمية، والنوعية. }
\end{aligned}
$$

ع . حماية الصناعات الناشئة، (وتشجيع الاستثمار وتعزيز قدرة الصناعة الوطنية على المنافسة لرفع كفاءة الاقتصاد الوطني)

ه. مراقبة حركة المسافرين والبضائع ووسائط النقل العابرة لحدود الدولة.

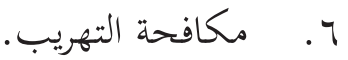

$$
\begin{aligned}
& \text { V. المساهمة في حماية البحتمع المحلي والبيئة من المواد الخطرة. } \\
& \text { الضوابط الشرعية المتعلقة بقيد الجمارك: }
\end{aligned}
$$

$$
\begin{aligned}
& \text { وهذه الضوابط الشرعية تقوم بتوجيه الضريبة الجمركية إلى الانضباط } \\
& \text { بالأحكام الشرعية، ومن هذه الضوابط: } \\
& \text { 1 . كون المال معدا للتجارة. } \\
& \text { r. - الانتقال بالتجارة خارج الإقليم. }
\end{aligned}
$$$$
\text { r. بلوغ المال المفروض عليه الجمارك النصاب. }
$$

ع. استيفاء الضريبة مرة واحدة سنويا من مواطني الدولة الإسلامية.26

24 Wajdī Maḥmūd Husāyn, “al-Ta'rīfah al-Jumrukiyah wa Awdā' al-Siyāsah al-Tijāriyah fī Ițār wa Ahdāf al-Inmā' al-Iqtișād wa al'Adālah al-Ijtimā'iyyah fī Mișr", Majallah Miṣr al-Mu'āṣirah vol. 423 (t.t), 53.

25 'Abd al-Mun'im Fawzī, al-Māliyah al- 'Āmmah wa al-Siyāsah alMāliyah (al-Iskandariyah: al-Mu'ārif, t.t), 146.

26 Muḥammad Naj̄̄b al-Jaw'ān̄̄, Dawābiṭ al-Tijārah fì al-Iqtiṣād alIslāmī (Bayrūt: Dār al-Kutub al-'Ilmiyyah, 2005), 455-456. 


\section{ويجب أن تعفى السلع من الضريبة الجممكية في الحالات التالية:. 27}

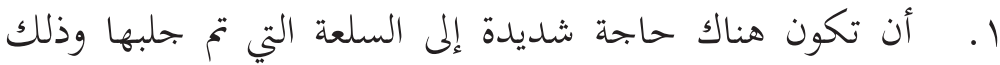

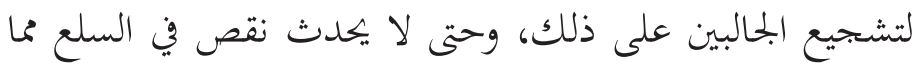

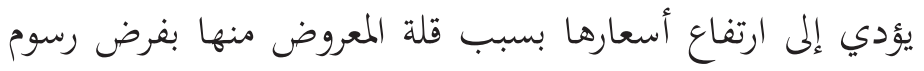
أو عشور عليها.

r أ أن تكون التجارة خاصة بالمسلمين. r. أن تقوم الدولة بمبادرة منها بإرادتّا المنغردة بوقف أو إلغاء ما تحصله

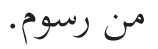

النوع الثاني: القيود المباشرة على السوق في الاستيراد والتصدير القيود المباشرة على السوق في الاستيراد والتصدير تكون بالرقابة المباشرة

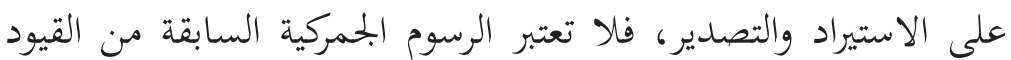

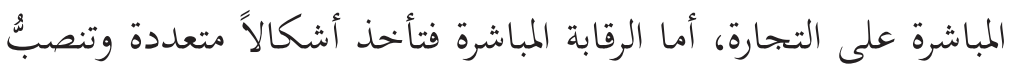

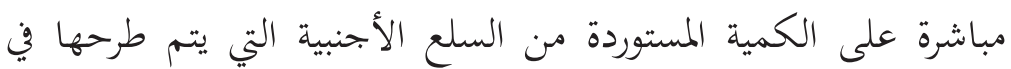

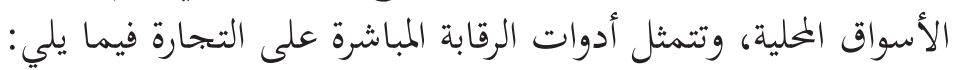

\section{القيد الأول: الرقابة على الصرف}

يعرف سعر الصرف: العلى أنه النسبة بين عدد الوفيدة الوحدات المتبادلة بين

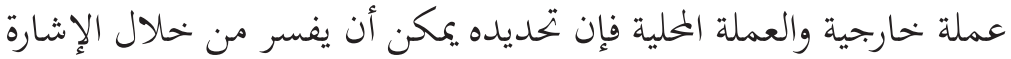

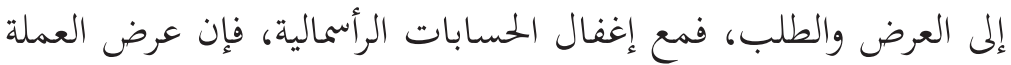
الوطنية أمر تحدده الواردات، فيما تحدد الصادرات الطلب على على هذه العملة المحلية).

Al-Wafā', al- 'Ilām bi Qawā'id al-Qānūn al-Duwal̄, 286.

Muhammad Najātullāh Șadīqī, Tadrīs 'Ilm al-Iqtiṣād al-Islāmī, alIqtiṣād al-Dawlī (Jeddah: Markaz al-Nashr al-'Ilmī, 2009), 32. 
》الرقابة على الصرف تعتبر من أدوات الرقابة المباشرة على التجارة، ويتم من

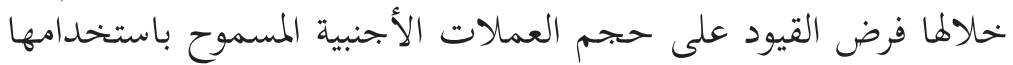

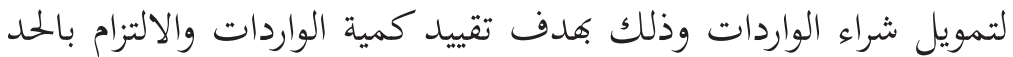
الأقصى للكمية المسموح باستيرادهاء؛.

تتحكم الدول بأسعار صرف العملات الأجنبية كقيد على التجارة الخارجية

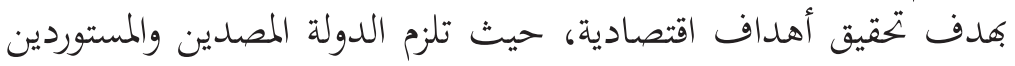

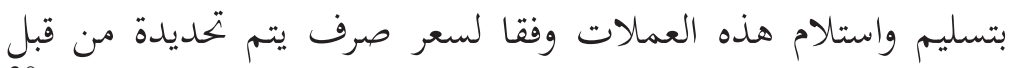

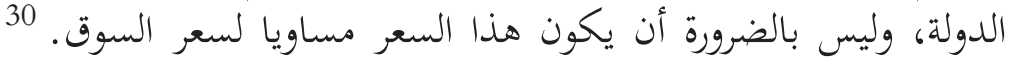

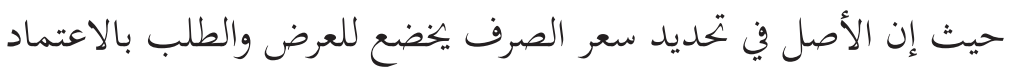

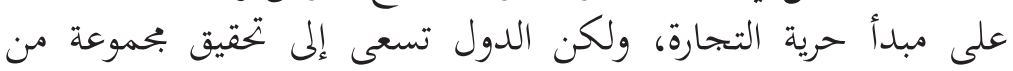
الأهداف الاقتصادية التي من أهمها:

1. مراقبة فعالية القيود السابقة، حيث أن التبادل التجاري لا يتم إلا عن طريق البنوك الدولية.

2. تقليل تأثير تقلبات سعر الصرف على السلع المستوردة والمصدرة. 3. ماية القودة الشرائية الوطنية.

هذه الأهداف وغيرها مما يسعى لتحقيقه هذا القيد والقيود السابقة.

\section{الضوابط الشرعية لقيد الرقابة على الصرف:}

بالنظر إلى مبدأ حرية التجارة الذي تعتمده الشريعة الاسلامية كأساس

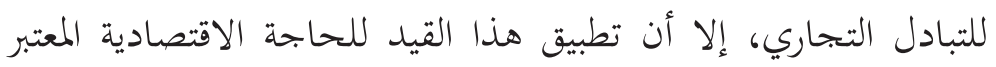

Al-Muqbalī, al-Ișlāhāt al-Iqtișādiyyāh, 25.

Ibid., 26. 
شرعا. 31 وتعتبر مراقبة عمليات التعامل في السوق الإسلامي من باب

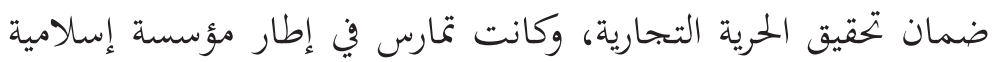

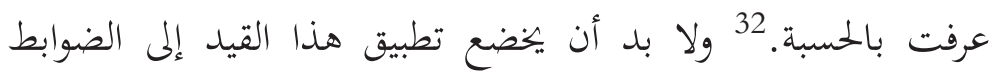

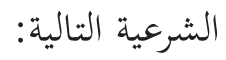

$$
\text { ا ـ بتجب الربا في المبادلات المالية. }
$$

r. أن يكون تغير الأسعار بسبب العرض والطلب، فلا تلجأ إليها الدولة إلا وفق سياسة واضحة وفي إطار الضرورة.

r. ترك المحال لحرية السوق في تحديد تبادل أسعار العملات، ويعتبر أي تدخل مؤقت بشرط تحقق المصلحة.

4. ماية القوة الشرائية للعملة الوطنية. 33 ضمن برنامج اقتصادي متكامل مصحوب بالإصلاحات الاقتصادية.

فسياسة الرقابة على الصرف لا تكون جائزة إلا بتحقق هذه الشروط،

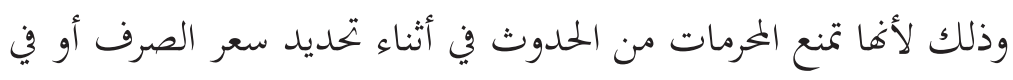
أثناء التعامل به.

\section{القيد الثاني: إعانات التجارة}

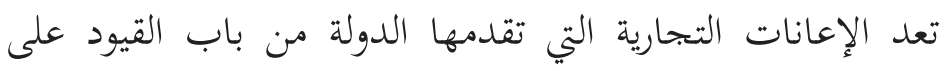

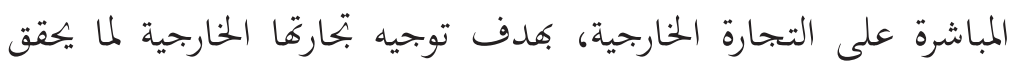

31 Nāṣir al-Marzūqī al-Biqmī, "Adawāt al-Siyāsāt al-Iqtiṣādiyyah wa Ḍawābituhā al-Shar'iyyah”, Majallah al-Diblūmāsī, 31 Shawāl (2006).

32 Iyād Muḥammad Aḥmad Malakāwī, "al-Munafisah fī al-Aswāq Bayn al-Sharī'ah al-Islāmiyyah wa al-Nizam al-Mu'āșirah” (Risālah Mājister, Jāmi'ah al-Yarmūk al-Urdun, 1990), 521- 522.

33 Al-Jaw'ānī, Dawābiṭ al-Tijārah fì al-Iqtiṣād al-Islāmī, 470 - 477. 
أهداف البلد اقتصاديا. وتأخذ الإعانات المقدمة من قبل الدولة الأشكال

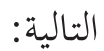

\section{النوع الأول: إعانات الاستيراد}

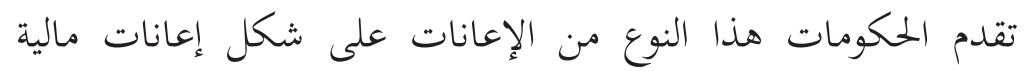

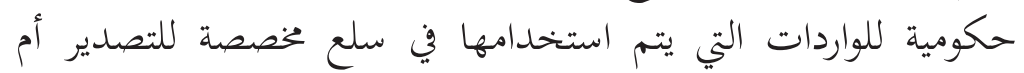

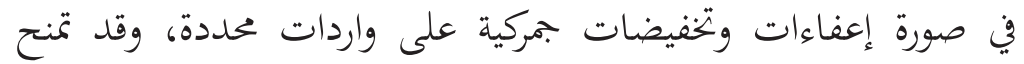

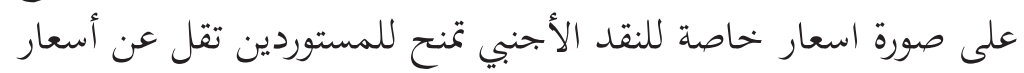
الصرف الرسمية السائدة.

النوع الثاني: إعانات النصدير:

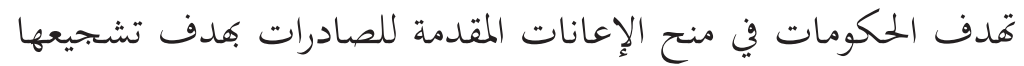

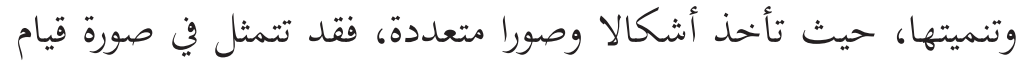

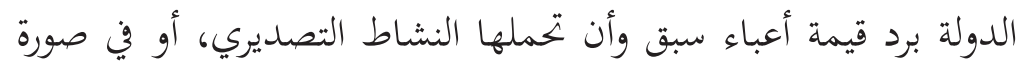

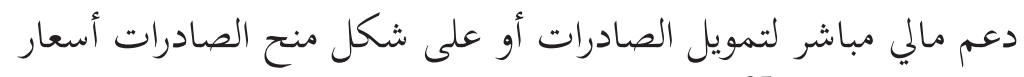

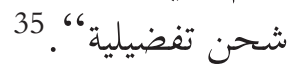

\section{الأهداف الاقتصادية لتطبيق هذا القيد:}

تتمثل الأهداف الاقتصادية من هذا القيد في بحموعة من الأهداف المرتبطة المدادئ

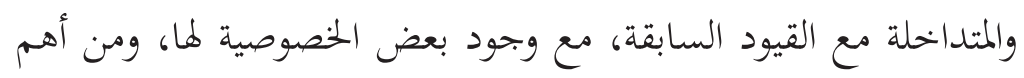

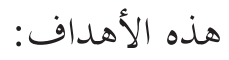

1. تشجيع استيراد السلع التي يمتاجها المختمع.

Al-Muqbalī, al-Ișlāhāt al-Iqtișādiyyāh, 26.

Al-Muqbalī, al-Iṣlāhāt al-Iqtișādiyyāh, 26. 
2. تشجيع الصادرات المحلية للوصول إلى الاكتفاء والاستقلال الاقتصادي. 3. مساعدة المواطنين في حالات معينة.

الضوابط الشرعية للإعانات التجارية:

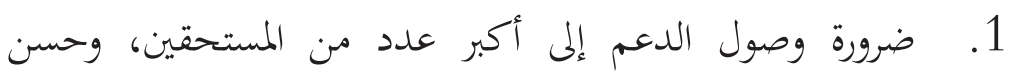

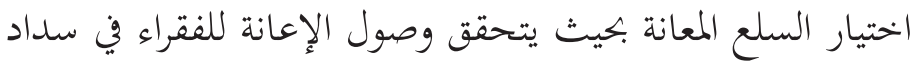

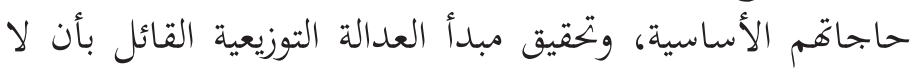

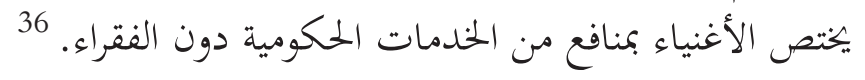

1. أن يكون مصدرها التمويلي من الإيرادات العامة غير المخصصة حيث لا يكون المصدر زكوياً. 37

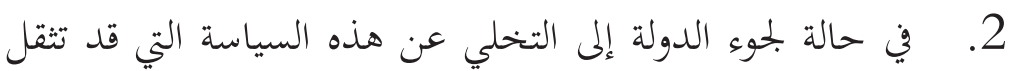

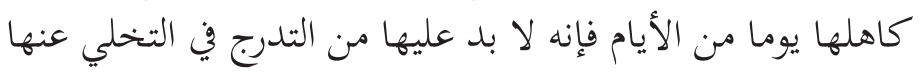

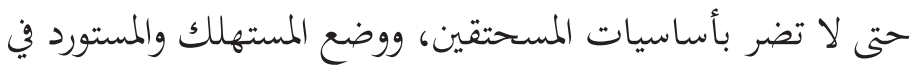
وضع حرج لم يكن يجسب حسابه.

وهذه الضوابط هي محاولة لضبط هذا القيد من الناحية الشرعية، ولابد من

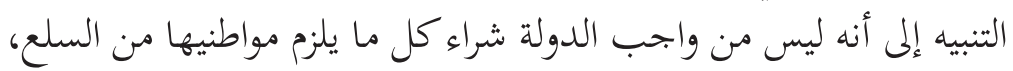

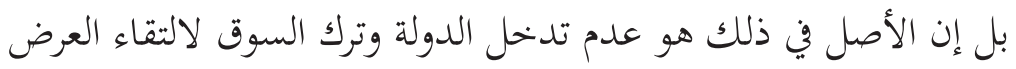
والطلب، وفتح باب المنافسة على مصراعيه.

36 Mundhir Qaḥf, al-Siyāsāt al-Māliyyah Dawruhā wa Dawābituhā fì al-Iqtișād al-Islāmī (Lubnān: Dār al-Fikr al-Mu'āșir, 1999), 69-73.

37 Ibid. 


\section{القيد الثالث: التجارة الحكومية}

تقوم كثير من الدول باحتكار التجارة الدولية من خلال التحارة الكارها

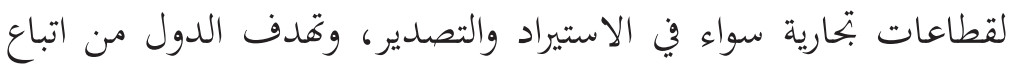
هذه السياسة أهدافاً اقتصادية من أهمها: 1. المحافظة على مستويات الأسعار. r. الوفاء بمتطلبات الأمن الغذائي. r. توفير احتياجيات القوات المسلحة، وغيرها من الأهداف. 38

\section{الضوابط الشرعية لقيد التجارة الحكومية:}

يجب أن تتوفر في هذا القيد الضوابط التالية:

$$
\text { 1. أن أن تكون التجارة مشروعة. }
$$

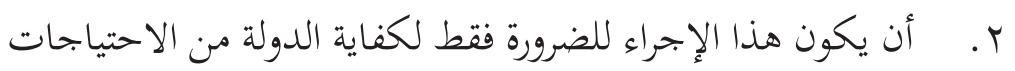

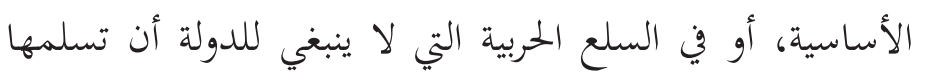
لمشركات الخاصة أو الأفراد.

$$
\text { r. أن يكون في الضروريات، والحاجيات (من المباحات). }
$$

ع. فتح باب المنافسة حتى لا يكون الاعتماد على مؤسسات معينة.

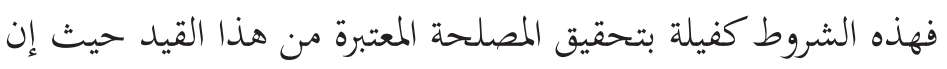

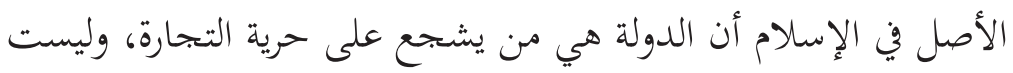
هي التي تحتكر السلع.

38 Al-Muqbalī, al-Iṣlāhāt al-Iqtiṣādiyyāh, 27. 
استعرضنا في هذا البحث أهم أدوات السياسة التجارية التي تستخدمها

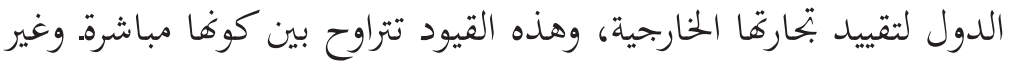
مباشرة، وقد توصل الباحث إلى النتائج التالية:

1. وجوب الاهتمام بوضع القيود على التجارة الدولية من الناحية الاقتصادية ومن الناحية الشرعة.

2. وجوب خضوع كل قيد من هذه القيود للمناقشة من قبل أصحاب

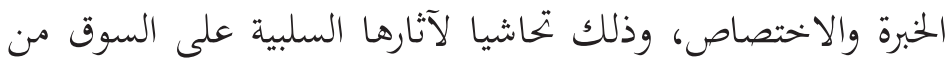

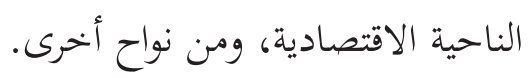

3. أن القيود المنظمة للتجارة الدولية وأنشطتها تعتبر من القيود المرنة التي تتغيير بتغير الزمان والمكان.

4. وجوب العدل والمساواة في فرض القيود على الاستيراد والتصدير بين

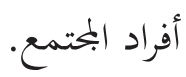

5. وجوب مراعاة أولويات السوق في الاستيراد والتصدير، وذلك بناءً على دراسات أهل الخبرة والتجربة.

6. وجوب تحقيق العدل بين التجار، والمستهلكين في التسهيلات التجارية.

7. ضرورة وضع المواصفات والمقاييس للسلع الداخلة والخارجة من وإلى

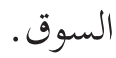

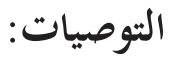

في ختام هذا البحث يوصي الباحث لتقديم المزيد من الجها لخدمة هذا الموضوع الهام من خلال التوصيات التالية: 


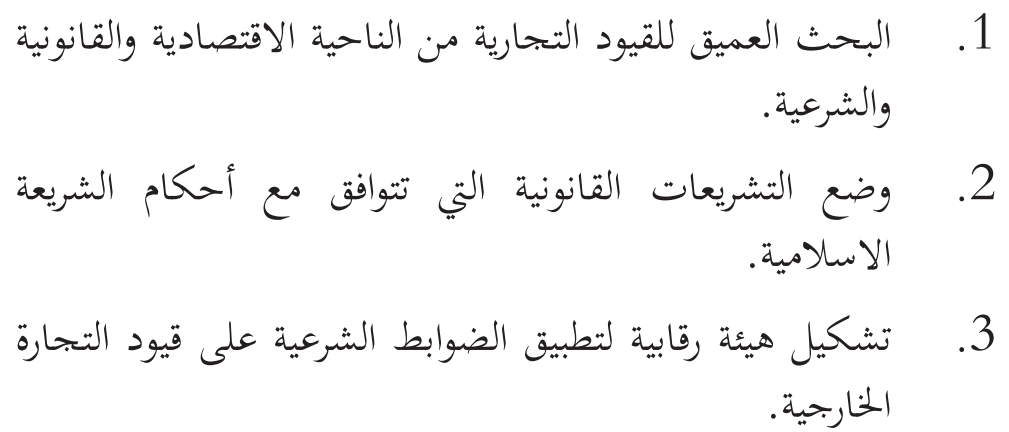

\section{REFERENCES}

'Abd al-Majīd 'Abdullāh, al-Qawā'id wa al-Ḍāwābit al-Fiqhiyyah li Ahkām al-Mubī' fì al-Sharī'ah al-Islāmiyyah ('Ammān: Dār al-Nufāis, 2005).

'Abd al-Mun'im Fawzī, al-Māliyah al- 'Āmmah wa al-Siyāsah alMāliyah (al-Iskandariyah: al-Mu'ārif, t.t.).

'Abd al-Salām Hārūn, Tahdhīb Sìrah Ibn Hisḥam (al-Kuwāyt: Dār al-Buhūth al-'Ilmiyyah, 1985).

'Ikāz, Muhammad 'Alī, al-Quyūd al-Shar'iyyah al-Wāridah 'alā Huriyyah al-Tijārah wa Atharuhā fì al-Tanmiyah Dirāsah Fiqhiyyah Muqāranah (Mișr: Dār al-Fikr al-Jāma'1̄, 2008).

'Ilā' al-Dīn al-Rifātī, al-Sūq wa Makānatuha fì al-Islām (t.tp: tp, 2006).

Abū Yūsuf Ya'qūb bin Ibrāhīm, al-Kharājj, ed.ke-3 (Qāhirah: alMațba'ah al-Salafiyyah, 1382H).

Aḥmad Abū al-Wafā', al-'Ilām bi Qawā'id al-Qānūn al-Duwal̄̄ wa al- 'Alāqāt al-Dawliyyah: F̄̄ al-Sharī'ah al-Islām, wa al- 'Alāqāt al-Iqtișādiyyah al-Dawliyyah fì al-Sharī'ah alIslāmiyyah, ed. ke-2 (Miṣr: Dār al-Nahḍah al-'Arabiyyah, 2007).

Al-Ḥimwī, Aḥmad bin Muhammad Makkī al-Husaynī, Ghamaz 'Uyūn al-Bașāir Sharh Kitāb al-Ashbāh wa al-Nazāir li Zayn al-'Ābidīn Ibn Nujaym al-Miṣr (Bayrūt: Dār al-Kutub al-'Imiyyah, 1405H).

Husāyn 'Umar, Mawsū'ah al-Muștalahāạt al-Iqtiṣādiyyah, cet. ke-3 (Jedah: Dār al-Shurūq, 1399H). 
Ibrāhīm Muștafā wa Ākharūn, al-Mu'jam al-Wasìt, ed. Majma' al-Lughah al-'Arabiyyah (t.tp: Dār al-Da'wah, t.t.).

Ismā'̄̄l bin Hammād al-Jawhurī, al-Ṣahāh Taj al-Luqhah wa Șahāh al-'Arabiyah, cet.ke-4 (Bayrūt: Dār al-'Ilm li alMalāyīn, 1990).

Iyād Muḥammad Aḥmad Malakāwī, "al-Munafisah fī al-Aswāq Bayn al-Sharī'ah al-Istāmiyyah wa al-Nizam al-Mu'āṣirah.” (Risālah Mājister, Jāmi’ah al-Yarmūk al-Urdun, 1990).

Kāmil Șakr 'Azīz, "Dawābiṭ Istikhdām al-Mawārid al-Bashariyyah fî al-Iqtișād al-Islāmī wa Athāruhā fĩ al-Tanmiyah." (Rișālah duktūrah, Jāmi'ah Baghdād, 1997).

Al-Majdhūb Asāmah, al-Jād wa Miṣr al-Buldān al-'Arabiyyah min Hāfan ilā Marākish 1947-1994 (al-Qāhirah: al-Dār alMișriyyah al-Libāniyyah, 1997).

Al-Miqdād 'Alī al-Shāmī, "al-Dawābit al-Shar'iyyah li al-Istīrād wa al-Tașdīr Dirāsah Taṭbīqiyyah 'alā Qānūn al-Tijārah alKhārijiyyah al-Yaman̄i li “Ām 2007.” (Risālah Duktūrah Jāmi' ah al-'Ulūm al-Islāmiyyah, 2012).

Muḥammad 'Al̄̄ Ḥizām al-Muqbalī, al-Iṣlāhāt al-Iqtiṣādiyyāh wa In'ikāsātihā 'alā al-Tijāraj al-Khārijiyyah fì alJumhüriyyah al-Yamaniyyah 1990-2001 (Sana'ā: Wizārah al-Thaqāfah wa al-Siyāḥah, 2001).

Muḥammad al-Sānūsī Muḥammad Shahātah, al-Tijārah alDawliyyah fì Daw' al-Fiqh al-Islāmī wa Ittifāqiyāt al-Jād Dirāsah Muqāranah (Mișr: Dār al-Fikr al-Jāma’1̄, t.t.).

Muhammad bin 'Alī Ibn al-Qāọ̄i Muḥammad Hamid bin Muḥammad Șābir al-Fārūqī al-Ḥanafī al-Ṭahānawī, Mawsū'ah Kasshāf Iștilāḥāt al-Funūn wa al-'Ulūm, ed. 'Alī Daḥrūj (Bayrūt: Maktabah Lubnān, 1996).

Muḥammad Muḥammad al-Ghazālī, Mushkilah al-Ighrāq Dirāsah Muqāranah (Miṣr: Dār al-Jāmi’ah al-Jadīdah, 2007).

Muhammad Najātullāh Șadīqī, Tadrīs 'Ilm al-Iqtiṣād al-Islāmī, alIqtiṣād al-Dawlì (Jeddah: Markaz al-Nashr al-'Ilmī, 2009).

Muhammad Najīb al-Jaw'ān̄̄, Ḍawābiṭ al-Tijārah fì al-Iqtișād alIslāmī (Bayrūt: Dār al-Kutub al-'Ilmiyyah, 2005). 
Muḥammad Șabrī Hārūn, al-Ahkām al-Aswāq al-Māliyyah alAshum wa al-Sanadāt Dawābìt al-Intifā' wa al-Tașarruf bihā fì al-Fiqh al-Islāmī (al-Urdūn: Dār al-Nufāis, 1999).

Muhammad Taqī al-'Uthmān̄̄, "Bay' al-Huqūq al-Mujridah," Majallah Majma' al-Fiqh al-Islāmī vol.5, no.3 (1948).

Mundhir Qaḥf, al-Siyāsāt al-Māliyyah Dawruhā wa Dawābituhā fì al-Iqtiṣād al-Islāmī (Lubnān: Dār al-Fikr al-Mu'āṣir, 1999).

Nāṣir al-Marzūqī al-Biqmī, "Adawāt al-Siyāsāt al-Iqtișādiyyah wa Ḍawābituhā al-Shar'iyyah”, Majallah al-Diblūmāsī, 31 Shawāl (2006).

Wajdī Mahmūd Husāyn, "al-Ta'rīfah al-Jumrukiyah wa Awdā' al-Siyāsah al-Tijāriyah fī Ițār wa Ahdāf al-Inmā’ al-Iqtișād wa al-'Adālah al-Ijtimā'iyyah fī Mișr", Majallah Miṣr alMu'āṣirah vol. 423 (t.t). 